\title{
CHARACTERIZATION OF KAPOK PERICARPIUM MICROCRYSTALLINE CELLULOSE PRODUCED OF ENZYMATIC HYDROLYSIS USING PURIFIED CELLULASE FROM TERMITE (MACROTERMES GILVUS)
}

\author{
YULIANITA PRATIWI INDAH LESTARI ${ }^{a}$, HERMAN SURYADI ${ }^{*}$, MIRAJUNNISAa, WIBOWO MANGUNWARDOYOb, \\ SUTRIYO' ${ }^{c}$ ARRY YANUAR ${ }^{\mathrm{d}}$
}

aLaboratory of Microbiology and Biotechnology, Faculty of Pharmacy, Universitas Indonesia, Pondok Cina, Depok, 16424, West Java, Indonesia, bLaboratory of Microbiology, Departement of Biology, Faculty of Mathematics and Sciences, Universitas Indonesia, Pondok Cina, Depok, 16424, West Java, Indonesia, cLaboratory of Technology of Pharmacy, And dLaboratory of Biomedical Computation, Faculty of Pharmacy, Universitas Indonesia, Pondok Cina, Depok, 16424, West Java, Indonesia Email: hsuryadi@farmasi.ui.ac.id

Received: 24 Nov 2019, Revised and Accepted: 08 Jan 2020

ABSTRACT

Objective: This study aimed to increase the yield of microcrystalline cellulose (MCC) from kapok pericarpium alpha-cellulose produced by enzymatic hydrolysis using purified cellulase from Termites (Macrotermes gilvus) and to compare the characteristics with the reference product.

Methods: In this research, MCC was prepared from kapok pericarpium powder through the chemical isolation process of alpha-cellulose, followed by enzymatic hydrolysis with purified cellulase from Macrotermes gilvus. The yield was improved by using purified cellulase in optimized temperature, $\mathrm{pH}$ and hydrolysis time. Identification was carried out by using $\mathrm{ZnCl}$ and infrared spectrophotometry, followed by characterization of MCC include particle size analysis (PSA) and diffractogram pattern (X-Ray Diffraction). The results were compared with Avicel PH 101 as the reference product.

Results: Purified cellulase from Macrotermes gilvus showed high cellulose activity. Cellulose in the concentration of $11.743 \mathrm{U} / \mathrm{ml}$ formed $49 \mathrm{~mm}$ clear zone area with cellulolytic index 7.16 that similar to the formed clear zone area of Trichoderma reesei (50 mm), the optimum hydrolysis condition was achieved at $50^{\circ} \mathrm{C}, \mathrm{pH} 6.0$, in $2 \mathrm{~h}$, which produced $80 \%$ yield of MCC. Produced MCC was analyzed with ZnCl and FTIR spectrum resulting in positive results, similar to reference. The results of the organoleptic test, particle size analysis, and diffractogram pattern (X-Ray Diffraction) showed crystalline characteristics of MCC is similar to the reference (Avicel PH 101)

Conclusion: Cellulase Macrotermes gilvus yielded $80 \%$ MCC and higher enzymatic activity than Trichoderma reesei. Based on the organoleptic test, particle size analysis, and diffractogram pattern observation, MCC from kapok pericarpium has shown similar characteristics to reference (Avicel pH 101) and might be potential to be further developed.

Keywords: Cellulase purification, Enzymatic hydrolysis, Kapok pericarpium, Macrotermes gilvus, MCC characterization, Microcrystalline cellulose

(C) 2020 The Authors. Published by Innovare Academic Sciences Pvt Ltd. This is an open access article under the CC BY license (http://creativecommons.org/licenses/by/4.0/) DOI: http://dx.doi.org/10.22159/ijpps.2020v12i3.36468. Journal homepage: https://innovareacademics.in/journals/index.php/ijpps

\section{INTRODUCTION}

Kapok fruits have a source of fiber that can be used as a basic material for mattresses, pillows, and clothing. The kapok rind can be used as a substitute for paper material while the bark is rich in potassium and the ashes can be used as fertilizer [1]. Kapok has been known to have high cellulose content consisted of 86.52 to $96.89 \%$ [2]

MCC is an additional ingredient commonly used in pharmaceutical food, cosmetics, and other products. MCC is one of the most important tablet excipients because of the binding properties of tablets in the direct compression tablet creation method [3]. MCC can be synthesized by different processes such as acid hydrolysis and enzymatic hydrolysis. The enzymatic hydrolysis process is more interesting when viewed from energy use because it can be carried out at low temperatures, while chemical hydrolysis requires high temperatures and uses chemicals that can pollute the environment, but enzymatic hydrolysis takes longer [4].

Source of the enzyme for enzymatic hydrolysis can be obtained from fungi, mold, and animal (for example: insect). Termite is one of the insects that can produce cellulase. In common, termites can eat all of the materials that obtained cellulose. Preparation of MCC from kapok pericarpium powder by enzymatic reaction has already performed by Suryadi et al. [5]. In our previous study, the enzyme that used was still in the form of crude enzymes while in this study using the purified enzyme. Besides that, in previous studies used local isolates and Trichoderma reesei while in this study using Macrotermes gilvus. Enzymatic hydrolysis using termites has already performed by Fagbohunka, Okonji, and Adenike [6]. In their study, cellulase was produced by Ametermes eveuncifer (Silverstri) Soldiers while in this study cellulase was produced by Macrotermes gilvus (different species). So, that it can be used as new knowledge about other types of mold and animals that can produce cellulase enzymes.

This paper reports the preparation of MCC from kapok pericarpium powder using an enzymatic method that used an enzyme from termites (Macrotermes gilvus) which was compared with reference (Avicel PH 101). Identification MCC was carried out by zinc iodinate and infrared spectrophotometry, followed by characterizations of microcrystalline cellulose compared to the reference, Avicel PH 101.

\section{MATERIALS AND METHODS}

Instruments

The instruments analysis used were autoclave (Hirayama) incubator (Memmert), oven (WTB Binder), analytical balance (Acculab), particle size analyzer (Cilas 1190), waterbath shaker hotplate stirrer (Corning), pH meter (Eutech), centrifugator (Kubota 6800), UV-Vis spectrophotometer (Shimadzu), pH meter, and X-ray diffractogram (Rigaku), vacuum oven (Hotpack), blender (Maspion), sieve, filter paper, ose, tweezer, column, pipette volume and other glasswares commonly used in laboratories.

Raw material

Kapok pericarpium (Ceiba pentandra) obtained from Balai Penelitian Tanaman Rempah dan Obat (Balitro), Cimanggu, Ciwaringin district, 
Central Bogor West Java, Indonesia, 16124 (6.5810 $\left.{ }^{\circ} \mathrm{S}, 106.7898^{\circ} \mathrm{E}\right)$. The mold used in this study was Trichoderma reesei and Trametes versicolor from Universitas Indonesia Culture Collection (UICC), Department of Biology, the Faculty of Mathematics and Natural Sciences, Universitas Indonesia. Termites used Macrotermes gilvus from trees in the Faculty of Pharmacy area, Universitas Indonesia.

\section{Chemical material}

The chemicals used in this study were Avicel PH 101 (aicma) as reference product, sodium hydroxide (Merck), sodium hypochlorite (Merck), sodium nitrite (Merck), sodium sulfite (Merck), Potato Dextrose Agar/PDA (DifcoTM), Potato Dextrose Broth/PDB (Merck), yeast extract (Himedia), tween 80 (Merck), Peptone (DifcoTM), ammonium sulfate (Merck, Germany), Diethylaminoethyl (DEAE)Cellulose resin, Glucose (Merck), dinitrosalicylic acid (Himedia), nitric acid (Merck), acetic acid (Merck), $\mathrm{KBr}$ powder (Merck), zinc chloride (Merck), potassium iodide (Bratachem), distilled water (Merck), double distilled water (Otsuka).

\section{Maintenance of mold isolates}

Trichoderma reesei and Trametes versicolor was maintenanced in PDA medium, incubation at $27{ }^{\circ} \mathrm{C}$ for $7 \mathrm{~d}$.

\section{Isolation of alpha-cellulose}

Biodelignification process was carried out using Trametes versicolor with modification $[7,8]$ with kapok pericarpium as substrate producing alpha-cellulose with lower lignin content, further delignized with $\mathrm{NaOH} 10 \%$ and $\mathrm{NaOCl} 3,5 \%$ to get a whiter result.

\section{Extraction of cellulase enzyme}

Termites were washed and rinsed with distilled water, the termites were carefully homogenized with $10 \mathrm{mmol}$ natrium acetate buffer pH 5.0 and 1 mmol EDTA. The mixture was collected and centrifuged at $15000 \mathrm{rpm}$ for $15 \mathrm{~min}$ at room temperature. The supernatant containing a crude enzyme was collected and stored in the refrigerator at $4{ }^{\circ} \mathrm{C}$ or $\min 10^{\circ} \mathrm{C}[6]$.

\section{Purification of cellulase}

Cellulase was purified through precipitation with ammonium sulfate [6], followed by dialysis with selofan [7], and finally by DEAE-C column chromatography [9].

\section{Characterization of cellulase}

Cellulase characterization was performed by optimization of $\mathrm{pH}$, temperature, and time of hydrolysis [6]. Each experiment was conducted in triplicate and the standard deviation for each experimental result was calculated.

\section{Screening of cellulase activity based on clear zone}

Cellulolytic microbial was determined using CMC media on petri dishes. The enzyme was dripped on paper disk by optimizing various volumes. After incubating for $24 \mathrm{~h}$ at room temperature, Lugol solution $0.1 \%(\mathrm{~b} / \mathrm{v})$ and $1 \% \mathrm{NaCl}$ solution was added. The cellulolytic activity was determined by the cellulolytic index value which represents the difference between the diameter of the clear zone and the diameter of the colony [10]. For comparison,
Trichoderma reesei (molds that are often used in research for cellulase enzyme extraction), was also cultured. Cellulolytic index can be calculated with the following formula:

$$
\text { Cellulolytic Index: } \frac{A-B}{B}
$$

$\mathrm{A}=$ the diameter of the clear zone $(\mathrm{mm}) ; \mathrm{B}=$ the diameter of paper disk (mm).

\section{DNS method}

Cellulase activity was determined based on the method conducted by Zhang et al. (2006) with Dinitro salicylic acid (DNS) reagent, with a slight modification, using $1 \%$ carboxymethyl-cellulose (CMC) as a substrate [6].

\section{Preparation and characterization of MCC by enzymatic hydrolysis}

Amount of $10 \mathrm{~g}$ of kapok pericarpium alpha-cellulose were dissolved into $100 \mathrm{ml}$ acetate buffer $(0.05 \mathrm{M}, \mathrm{pH} 4.8)$ and $3 \mathrm{ml}$ of cellulase enzyme was added and stirred slowly. The mixed solution was stirred at $150 \mathrm{rpm}$ at $48^{\circ} \mathrm{C}$ for $72 \mathrm{~h}$ on a water shaking incubator. The mixture was centrifuged at $10,000 \mathrm{rpm}$ (at $7-10^{\circ} \mathrm{C} 20 \mathrm{~min}$ ). The precipitated residue was washed with distilled water to remove the remaining enzymes on cellulose and then dried with an oven at $60^{\circ} \mathrm{C}$ for $48 \mathrm{~h}[8]$.

\section{Identification with zinc iodinate}

Zinc iodinate solution was prepared by dissolving $20 \mathrm{~g}$ of zinc chloride and $6.5 \mathrm{~g}$ of potassium iodide in $10.5 \mathrm{ml}$ of water, follow by the addition of $0.5 \mathrm{~g}$ iodine, and shake for $15 \mathrm{~min}$. About $10 \mathrm{mg}$ of MCC was added to the watch glass and was then dissolved into $2 \mathrm{ml}$ of zinc chloride solution [11]. The compound formed will produce a violet-blue color.

\section{Infrared spectrophotometry (FTIR)}

The amount of $99 \mathrm{mg} \mathrm{KBr}$ powder which has been dried at $105^{\circ} \mathrm{C}$ for $24 \mathrm{~h}$ was weighed carefully and was added with $1 \mathrm{mg}$ MCC powder. The mixture was crushed and mixed until homogeneous, put into a disk or disc-shaped mold. $\mathrm{KBr} 100 \mathrm{mg}$ was weighed for a blank and a baseline. A Scanning was performed in $4000 \mathrm{~cm}^{-1}$ to $400 \mathrm{~cm}^{-1}$ wave number area [12]. The MCC FTIR spectrum made from kapok pericarpium pulp was then compared to the FTIR spectrum from reference raw materials (Avicel PH 101).

\section{Organoleptic examination}

Samples of MCC were placed on a white base (parchment paper or other suitable paper) and then observed for the shape or appearance, the color, the taste, and the smell [13].

\section{Size analysis and particle size distribution}

Particle size distribution was determined using Particle Size Analyzer Mikro (CILAS1190 Liquid) [11].

\section{$\mathrm{X}$-ray diffraction analysis}

Crystal analysis was performed using X-ray diffraction (XRD) (Rigaku Miniflex 600) [5].
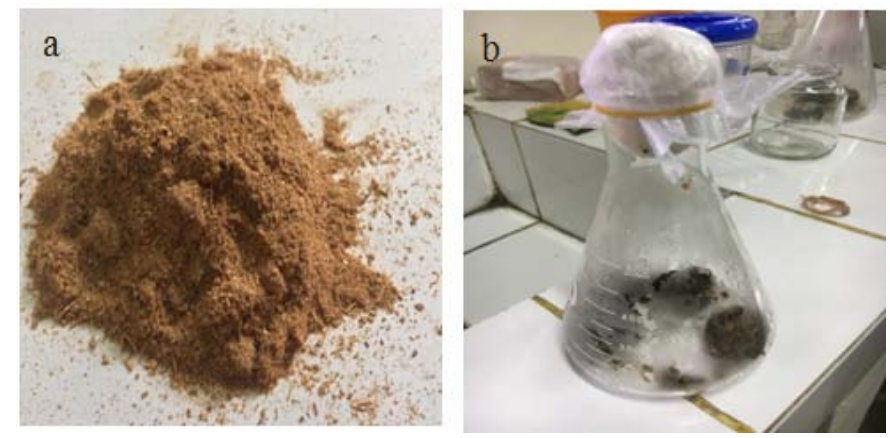

Fig. 1: Kapok pericarpium powder (a), sterilized kapok pericarpium powder (b) 


\section{RESULTS}

\section{Preparation of alpha-cellulose}

Biodelignification alpha-cellulose was prepared before the process. Kapok pericarpium powder was moistened with distilled water, then sterilized using an autoclave (fig. 1a and 1b).

\section{Biodelignification}

Biodelignification is the process of removing lignin from substrate (kapok pericarpium) biomass using biological organisms. In this study, biodelignification was carried out using cellulase isolated from the mold (Trametes versicolor).
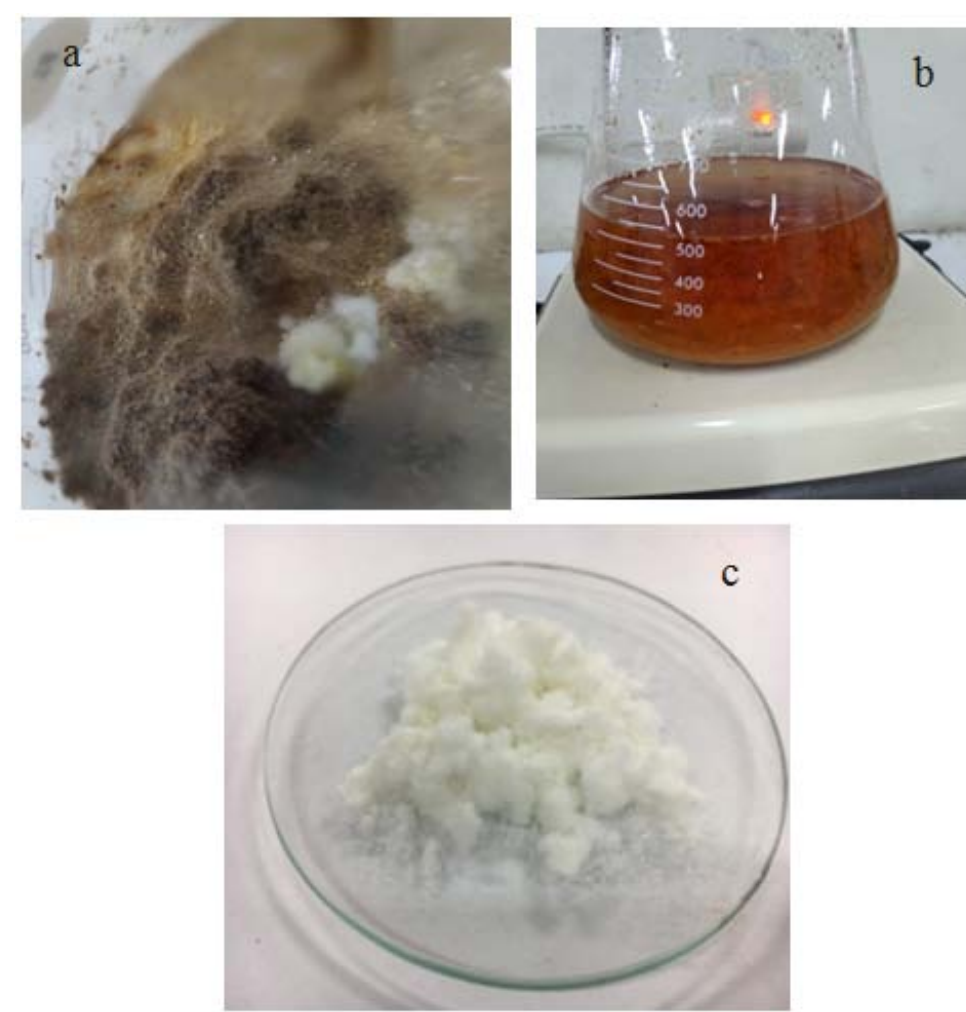

Fig. 2: Process of biodelignification (a), bleaching (b), and alpha cellulose obtained (c)

Biodelignification was carried out during $21 \mathrm{~d}$ using Trametes versicolor, white-colored mold covers the surface of the substrate (fig. $2 \mathrm{a}$ ), further delignification (fig. 2b) has yellowis-white color, finally, the whitest color was obtained (fig. 2c). The result of $\alpha$-cellulose isolation obtained from $5 \mathrm{~g}$ of substrate powder was $3.8 \mathrm{~g}(76.0 \%)$.

\section{Extraction of cellulase enzyme}

Extraction was carried out for hydrolysis enzymatic by mixing termites into buffer acetate solution $\mathrm{pH} 5.0$ to adjust the stabilize conditions of the enzyme stored in the body of termite.

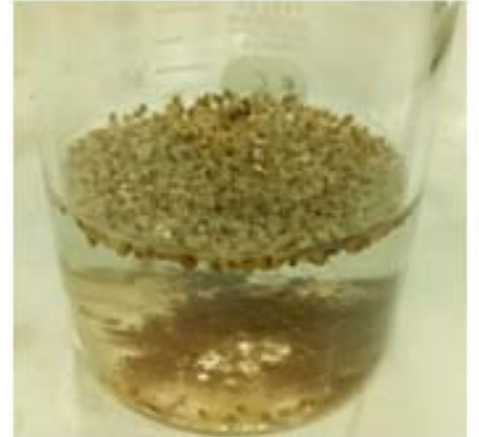

a

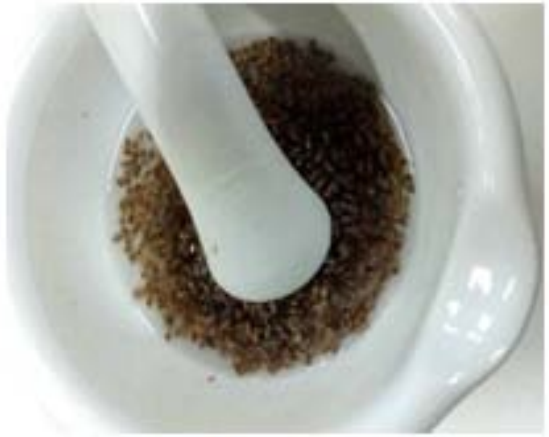

b

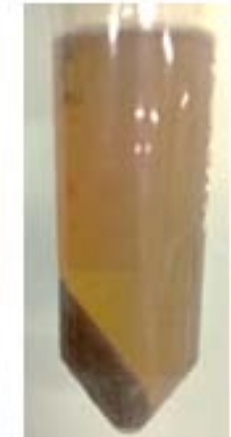

C

Fig. 3: (a) cleaning of termites from remaining soil on the body of termites; (b) homogenizing of termites with adding acetate buffer $\mathrm{pH}$ 5.0 ; (c) result of centrifugation (supernatant) as crude enzyme extract

Fig. 3a cleaning of termites from remaining soil on the body of termites, followed by homogenizing of termites with adding acetate buffer $\mathrm{pH} 5.0$ (fig 3b), and finally centrifugation (supernatant) as crude enzyme extract was kept in $4^{\circ} \mathrm{C}$ (fig. 3c).

\section{Purification of cellulase}

Purification process using Ammonium sulfate salt, dialysis, and column chromatography DEAE-C. The summary result was in table 1. 
Table 1: Summary of the stages of cellulase purification

\begin{tabular}{|c|c|c|c|c|c|c|c|c|}
\hline Steps & $\begin{array}{l}\text { Volume } \\
\text { (ml) }\end{array}$ & $\begin{array}{l}\text { Protein } \\
(\mathrm{mg} / \mathrm{ml})\end{array}$ & $\begin{array}{l}\text { Total } \\
\text { protein } \\
\text { (mg) }\end{array}$ & $\begin{array}{l}\text { CMCase } \\
\text { activity } \\
(\mathrm{mU} / \mathrm{ml})\end{array}$ & $\begin{array}{l}\text { Total cellulose } \\
\text { activity } \\
(\mathrm{mU})\end{array}$ & $\begin{array}{l}\text { Specific activity } \\
\text { (mU/mg) }\end{array}$ & $\begin{array}{l}\text { Purification } \\
\text { fold }\end{array}$ & Yield (\%) \\
\hline $\mathrm{CE}$ & 90 & 1703.33 & 153299.7 & 12593 & 1133370 & 7.393 & 0 & 100 \\
\hline & \multicolumn{8}{|c|}{ Fractination with ammonium sulfate } \\
\hline F1 & 10 & 1350 & 13500 & 11623 & 116230 & 8.610 & 1.165 & 10.255 \\
\hline $\mathrm{F} 2$ & $\begin{array}{l}75 \\
\text { Dialysis }\end{array}$ & 270 & 20250 & $\mathrm{TT}$ & $\mathrm{TT}$ & TT & TT & TT \\
\hline \multirow[t]{2}{*}{ Dt } & 10 & 1190 & 11900 & 12062 & 120620 & 10.136 & 1.371 & 10.643 \\
\hline & \multicolumn{8}{|c|}{ Ion exchange chromatography (DEAE-Streamline) } \\
\hline P1 & 5 & 1050 & 5250 & 11743 & 58715 & 11.184 & 1.513 & 5.181 \\
\hline $\mathrm{P} 2$ & 5 & 1030 & 5150 & 11150 & 55750 & 10.825 & 1.465 & 4.919 \\
\hline P3 & 5 & 970 & 4850 & 10600 & 53000 & 10.928 & 1.478 & 4.676 \\
\hline $\mathrm{P} 4$ & 5 & 850 & 4250 & 8663 & 43315 & 10.192 & 1.379 & 3.822 \\
\hline P5 & 5 & 830 & 4150 & 8200 & 41000 & 9.880 & 1.336 & 3.618 \\
\hline P6 & 5 & 250 & 1250 & $\mathrm{TT}$ & $\mathrm{TT}$ & $\mathrm{TT}$ & $\mathrm{TT}$ & $\mathrm{TT}$ \\
\hline P7 & 5 & 230 & 1150 & TT & $\mathrm{TT}$ & TT & TT & TT \\
\hline
\end{tabular}

The highest activity during the purification process was the first fraction (P1) with the specific activity $11.184 \mathrm{mU} / \mathrm{mg}$ and purity grade 1.51 times compare to the crude enzyme.

\section{Characterization of cellulase}

\section{Effect of $\mathrm{pH}$ variation}

The activity of cellulase was determined at various $\mathrm{pH}$ ranges from 3.0-8.0 (fig. 4), the highest activity of cellulase was at $\mathrm{pH} 6.0$ with the activity $7.29 \mathrm{U} / \mathrm{ml}$.

\section{Effect of temperature variation}

The activity of cellulase was determined at various temperatures ranges from 30 to $60^{\circ} \mathrm{C}$ (fig. 5). The highest activity of cellulase was at $50^{\circ} \mathrm{C}$ with the activity $12.78 \mathrm{U} / \mathrm{ml}$.

\section{Optimization duration of hydrolysis}

Optimization of hydrolysis duration was carried out during $10 \mathrm{~h}$, the results indicate that the lowest glucose concentration was hydrolysis in $2 \mathrm{~h}$ incubation (fig. 6).

Screening of clear zone-based cellulase activity in medium CMC

The crude enzyme of Macrotermes gilvus showed a clear zone with a diameter of $42 \mathrm{~mm}$ and $49 \mathrm{~mm}$ and the cellulolytic index of 63.9 and 76.3 , Trichoderma reesei showed a clear zone diameter of $50 \mathrm{~mm}$ and cellulolytic index 7.3 which means that Macrotermes gilvus has almost the similar results as Trichoderma reesei in term oh hydrolysis activity

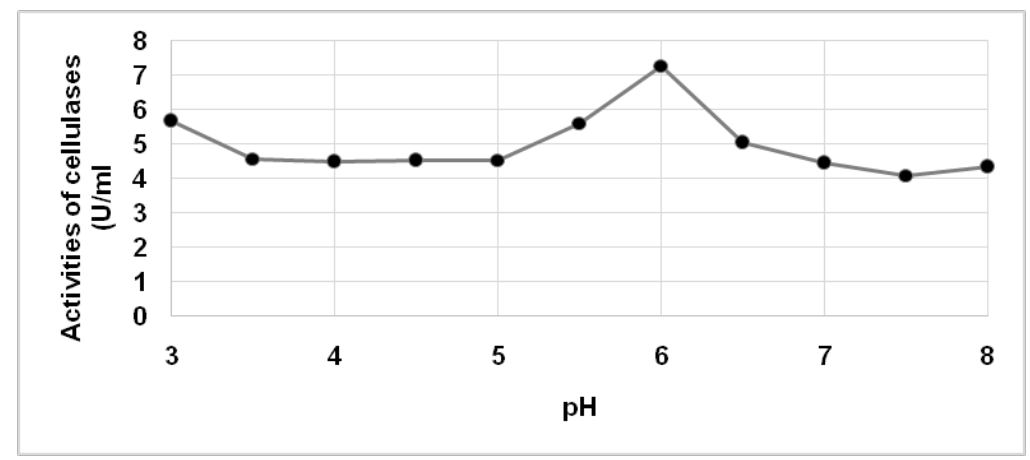

Fig. 4: Effect of $\mathrm{pH}$ on the activities of cellulases from Macrotermes gilvus, all values are reported as mean \pm SD (Standard deviation), triplicates

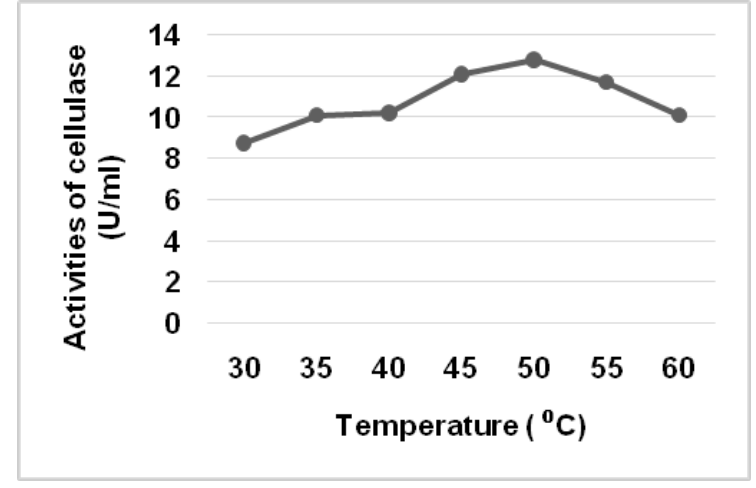

Fig. 5: Effect of temperature on the activities of cellulases of Macrotermes gilvus, all values are reported as mean \pm SD (Standard deviation), triplicates 


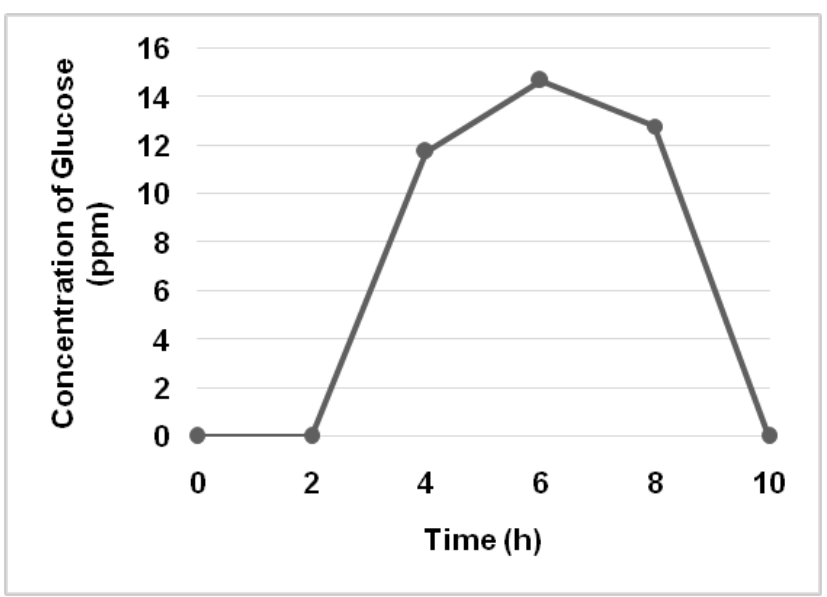

Fig. 6: Optimization duration of hydrolysis, all values are reported as mean \pm SD (Standard deviation), triplicates

Table 2: Results of screening of cellulase activities based on the formed clear zones in CMC media

\begin{tabular}{lll}
\hline Mold & The diameter of the clear zone $(\mathbf{m m})$ & The diameter of the petri dish (mm) \\
\hline TR & 50 & $6 \pm 0.00$ \\
MG $(5 \mu \mathrm{l})$ & 42 & $6 \pm 0.00$ \\
MG $(10 \mu \mathrm{l})$ & 49 & $6 \pm 0.00$ \\
\hline
\end{tabular}

$\mathrm{TR}=$ Trichoderma reesei, $\mathrm{MG}=$ Macrotermes gilvus, All values are reported as mean \pm SD (Standard deviation), triplicates

\section{Quantitative test (DNS method)}

The linear regression equation $y=0,0099 x-0,4097 ; R^{2}=0,9963$ was then applied to calculate glucose concentration and cellulase enzyme activity in the sample.

\section{Preparation and characterization of MCC by enzymatic hydrolysis}

Alpha-cellulose, buffer, and purified enzyme were mixed and stored to incubator shaker settled at $50{ }^{\circ} \mathrm{C}$, speed of $125 \mathrm{rpm}$ for $2 \mathrm{~h}$ (according to the temperature, $\mathrm{pH}$ and optimal hydrolysis time) to produce MCC. Then, the obtained MCC was identified and characterized as below.
The qualitative identification resulted in a violet purple after $\mathrm{ZnCl}$ drops were added of both two samples that the samples contained cellulose was indicated. According to Werner's Nomenclature of Color by Syme (1821), the violet color of Avicel PH 101 has Purples No. 40 (Imperial Purple) and the sample has Purples No. 41 (Auricula Purple).

\section{FTIR}

Although there were small differences between the reference and the sample, the FTIR spectrum showed a common characteristics spectrum of MCC (fig. 8).

Table 3: Results of the yield of MCC

\begin{tabular}{llll}
\hline Mold & Weight of alpha-cellulose & Weight of MCC & Yield \\
\hline TR & 10 & 8.75 & $87,5 \%$ \\
CC & 10 & 8 & $80 \%$ \\
\hline
\end{tabular}

$\mathrm{n}=1$
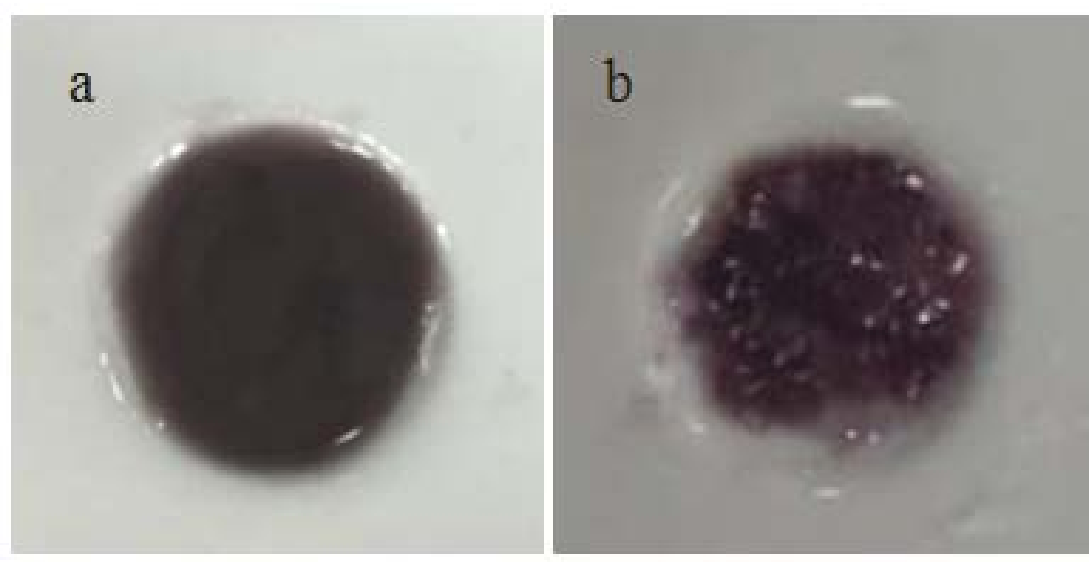

Fig. 7: Qualitative identification of samples using $\mathrm{ZnCl}$ (left: Avicel; right: sample) 


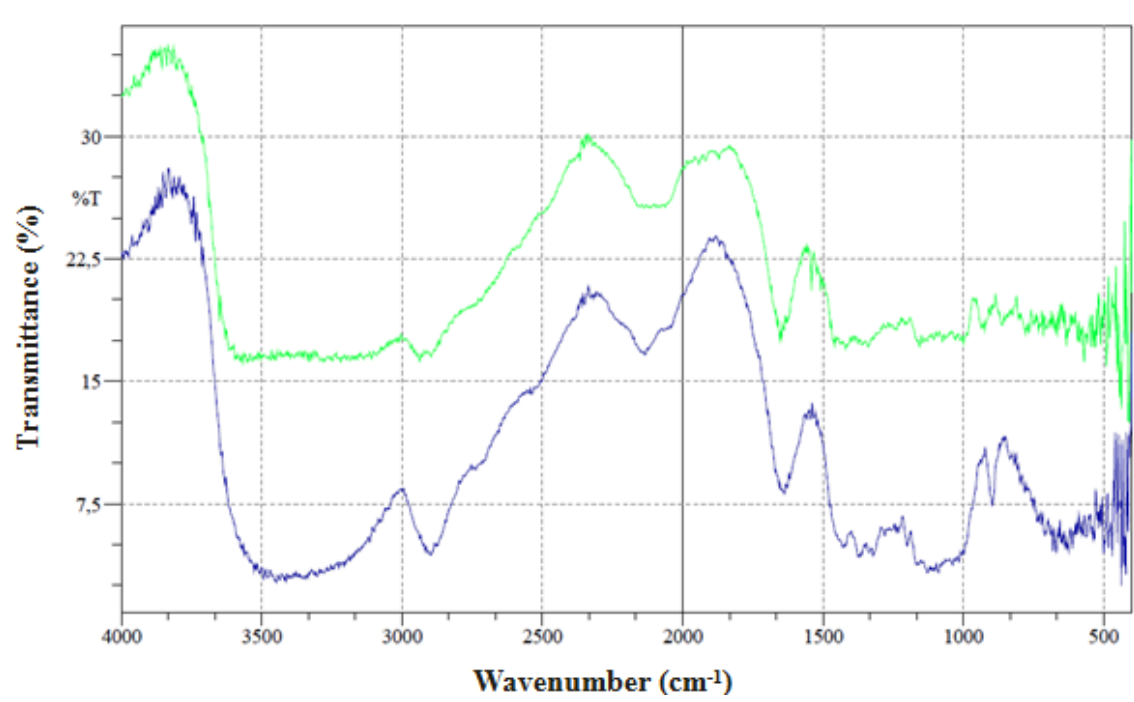

Fig. 8: Comparison of the results of avicel PH-101 (a, green) reference FTIR spectrum with the sample (b, blue)

MCC that produced in this study was characterized using FTIR. Characterization was using FTIR aimed to determine the functional groups in the sample. Fig. 8 shows a generated FTIR spectrum from the sample. The FTIR spectrum of the sample showed peaks at wavenumbers $3512.49,2908.75,1647.26,1419.66,1163.11$, and 898.86. While the Avicel spectrum as a reference shows peaks at numbers $3576.14,2937.68,1647.26,1419.66,1155.4,923.93$. The peaks indicate the presence of $\mathrm{O}-\mathrm{H}, \mathrm{C}-\mathrm{H}, \mathrm{C}=\mathrm{O}, \mathrm{C}-\mathrm{O}-\mathrm{C}$, and $\mathrm{C}-\mathrm{O}$ stretching groups, and $\mathrm{C}-\mathrm{H}_{2}$ and $\mathrm{C}-\mathrm{H}$ bending.

Based on the infrared spectrum, it can be seen some functional groups. Like at a wavelength of $3500 \mathrm{~cm}^{-1}$ a wide band was showed the presence of $\mathrm{OH}$ groups. In the $2895.25 \mathrm{~cm}^{-1}$ was shown a $\mathrm{C}-\mathrm{H}$ aliphatic bond and in the wavelength $1647.26 \mathrm{~cm}^{-1}$ was frequencies of deformation vibrations of $\mathrm{CH}_{2}$. The presence of glycosidic C-O-C was showed in the $1419.66 \mathrm{~cm}^{-1}$ band and $898.86 \mathrm{~cm}^{-1}$ was $\beta$ - glycosidic. Based on literaturefor Avicel as a reference was showed the following vibration peaks of cellulose: $3445 \mathrm{~cm}^{-1-}$ corresponding to intramolecular $\mathrm{OH}$ stretching, including hydrogen bonds, 2898 $\mathrm{cm}^{-1}$ due to $\mathrm{CH}$ and $\mathrm{CH}_{2}$ stretching, $1650 \mathrm{~cm}^{-1}$ corresponding to $\mathrm{OH}$ from absorbed water, $1430 \mathrm{~cm}^{-1}$ due to $\mathrm{CH} 2$ symmetric bonding, $1375 \mathrm{~cm}^{-1}$ due to $\mathrm{CH}$ bending, $1330 \mathrm{~cm}^{-1}$ due to $\mathrm{OH}$ in-plane bending, $1161 \mathrm{~cm}^{-1}$ due to C-O-C asymmetric stretching, $1061 \mathrm{~cm}^{-1}$ due to C-O$\mathrm{C}$ stretching, and $898 \mathrm{~cm}^{-1}$ corresponding to asymmetric (rocking) C1 ( $\beta$-glycosidic linkage) out of the plane stretching vibrations.

\section{Organoleptic test}

From the produced MCC and comparison to the reference Avicel PH 101 (fig. 9). it can be seen that the color produced from the sample is almost the same as Avicel, except that the grain is still rather rough and not as smooth as Avicel PH 101, but the difference is not too significant.
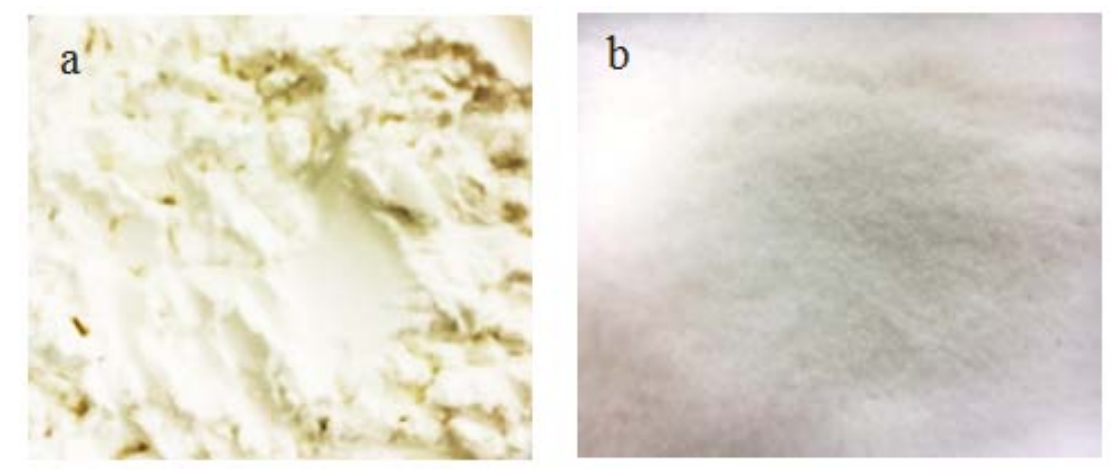

Fig. 9: The result of organoleptic on avicel PH-101 (a) and sample (b)

Table 4: Results of particle analysis on the sample with particle size analysis (PSA)

\begin{tabular}{|c|c|c|c|c|}
\hline & $\operatorname{dv10}(\mu \mathrm{m})$ & $\operatorname{dv50}(\mu \mathrm{m})$ & dv90 ( $\mu \mathrm{m})$ & Mean $(\mu \mathrm{m})$ \\
\hline Reference Avicel PH-101 & 6.25 & 15.61 & 24.00 & 15.56 \\
\hline Sample & 12.63 & 36.43 & 162.13 & 66.31 \\
\hline
\end{tabular}

$\mathrm{dv}=$ diameter over volume, $\mathrm{n}=1$ measurement

\section{Size analysis and particle size distribution}

Results of particle analysis on the sample using Particle Size Analyzer. Avicel PH 101 has 10\% from the total of particle size 1,181 $\mu \mathrm{m}, 50 \%$ from the total of particle size $13,72 \mu \mathrm{m}$, and $90 \%$ from the total of particle size $30,52 \mu \mathrm{m}$ with average $15,46 \mu \mathrm{m}$ (table 4 ).

\section{X-Ray diffraction analysis of MCC}

From the result of XRD analysis, the crystal and the amorphous of the sample is shown on the value of $2 \theta$ (deg). In the hydrolysis result of the sample, there 2 peaks that indicated the existence of crystal character at 22.58 with intensity 634 and 21.85 with intensity 513 . 
For amorphous nature, there is 1 peak at $2 \theta(\mathrm{deg})$ value at 12.779 with intensity 418 . The presence of crystalline and amorphous peak is influenced by the source of samples derived from kapok pericarpium and the manufacture of $\alpha$-cellulose using a strong base to remove lignin. The diffractogram from the sample is almost the same as Avicel, the difference is not too significant (fig. 10).
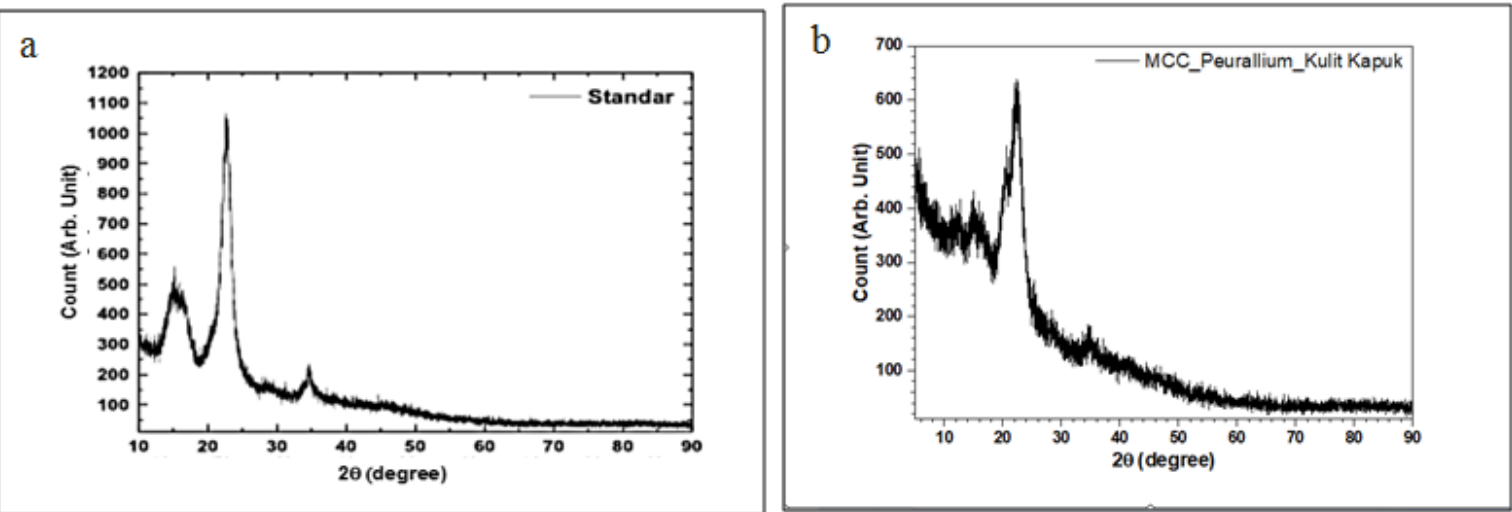

Fig. 10: Diffractogram of reference (a) and sample (b)

\section{DISCUSSION}

Biodelignification was carried out during $21 \mathrm{~d}$ using Trametes versicolor, the result of $\alpha$-cellulose isolation obtained from $5 \mathrm{~g}$ of substrate powder was $3.8 \mathrm{~g} \mathrm{(76.0 \% ).} \mathrm{According} \mathrm{to} \mathrm{Balat,} \mathrm{Balat,} \mathrm{and}$ $\mathrm{Oz}$ (2008) [14], biodelignification was pre-treatment for reducing the lignin component. Follow with the incubation process of kapok pericarpium and mycelium of Trametes versicolor in $30 \mathrm{~d}$ at $30^{\circ} \mathrm{C}$ and for $21 \mathrm{~d}$ at $40^{\circ} \mathrm{C}$ with the addition of nutrient solution. The mold of Trametes versicolor produces ligninolytic enzymes Laccase, $\mathrm{Mn}$ peroxidase (MnP), and Li peroxidase (LiP) $[15,16]$.

Purification process using Ammonium sulfate salt, dialysis, and column chromatography DEAE-C. In precipitation of ammonium sulphate, the process was carried out to purify the enzyme using the salting-out method assumed that at high salt concentrations (saturation) will increase the hydrophobic interaction between protein and water, where water will tend to be attracted by salt ions so that the solubility of the protein in water will decrease and protein deposition occurs. therefore these proteins will separate from each other depending on the different sizes of protein molecules contained in the solution [17].

The highest activity during the purification process was the first fraction (P1) from the column chromatography DEAE-C with the specific activity $11.1838 \mathrm{mU} / \mathrm{mg}$ and purity grade 1.51 times compare to the crude enzyme. Diethylaminoethyl cellulose (DEAE-C) is a positively charged resin [18]. P1 has the same ion charge as the matrix (resin DEAE-C) so that the enzyme can be get away from the column. The enzyme cellulase has a variation of ion charges when cellulase passed into the anion exchange matrix that has a positive charge, there will be fractination based on affinity of ion charge [19].

The sample of cellulase used in this experiment is the supernatant of the crude enzyme from the isolate of the termites. The addition of Lugol as a dye to make it easier and measure that the clear zone formed. Lugol reagent will be bound at 1.4- $\beta$ that will provide blueblack color of glycoside on cellulose. Meanwhile, the transparent color showed that cellulose has been hydrolyzed into monosaccharides, so that can not form a complex with iodine of Lugol. The ability to form a clear zone on a specific media indicates that the sample can produce the cellulolytic enzyme [20]. The change in $\mathrm{pH}$ affects the functional group ionization which can cause enzyme confrontation and its catalytic properties which will affect the hydrogen bonds contained in the enzyme. The change of enzyme confrontation can result in a decrease in enzyme activity caused by enzyme confrontation that is different from substrate confrontation. From the previous study, an optimum $\mathrm{pH}$ from the cellulose of Macrotermes gilvus of 8 was obtained for cellulose and temperature on the activity of cellulase showed the enzyme to have its optimum temperature at $50{ }^{\circ} \mathrm{C}$. In this study, optimum pH was 6.0 and the optimum temperature was $50{ }^{\circ} \mathrm{C}$. This condition was used at reference, in which cellulases with $\mathrm{pH}$ values of 4.5 to 6.0 are common, and the optimum temperature was according to the previous study which was $50{ }^{\circ} \mathrm{C}[21]$.

Temperature is closely related to the energy needed by enzymes to react. The lower the temperature, the enzyme does not have enough energy to react. The optimum temperature of the enzyme can work optimally whereas if the enzyme is at a temperature optimum then the ability of the enzyme will decrease due to enzyme denaturation by heat. Optimum cellulase activity shows that environmental conditions (such as $\mathrm{pH}$ and temperature) are right for cellulase to react with the substrate at $\mathrm{pH} 6.0$ and $50{ }^{\circ} \mathrm{C}[22]$. All enzymes work at a certain temperature. Most enzymes have optimum activity in the temperature range of $20-50{ }^{\circ} \mathrm{C}$. Whereas cellulase has optimum activity in the temperature range of $50-80{ }^{\circ} \mathrm{C}$ included in the thermozymic group or often referred to as thermolabel (heat resistant) [23]. Based on this study, cellulase obtained from Macrotermes gilvus belongs to the thermozymic group, stable at high temperatures.

Deng, Cui, Qi, Wang, Hou, and Zhu (2012) [24] reported the use of $\mathrm{ZnCl}_{2}$ solution as a carbohydrate reaction medium which includes cellulose, glucose, sucrose, maltose, starch, and fructose. They confirmed that the $\mathrm{ZnCl}_{2}$ solution with a concentration of $60 \%$ by weight can dissolve cellulose by forming a $\mathrm{Zn}$-cellulose complex. So it can be concluded that the function of zinc iodinate is $\mathrm{ZnCl}_{2}$ as a solvent for cellulose and iodine as a color modifier of cellulose to blackish blue-violet because iodine will give a violet-blue color to carbohydrate compounds and their derivatives.

Particle size and distribution analysis was performed using a micro Particle size analyzer (PSA) to determine the size and distribution of particles from the enzymatic hydrolysis samples from kapok pericarpium compared to the comparative sample Avicel PH 101. The results of particle size and distribution analysis depend on acid concentration, temperature, time, hydrolysis procedures, and mechanical processes [25].

The results of particle distribution analysis is known that the comparator Avicel PH 101 has $10 \%$ of the total particle size has a particle size of fewer than $1,181 \mu \mathrm{m}, 50 \%$ of the total particle size has a particle size of less than $13.72 \mu \mathrm{m}$, and $90 \%$ of the total particle size has particle size is less than $30.52 \mu \mathrm{m}$ with an average of $15.46 \mu \mathrm{m}$. The FTIR spectrum of the sample showed spectrum characteristics similar to microcrystalline cellulose.

Based on the XRD spectrum, Avicel has type I and the sample has type II. This is because the MCC sample comes from nature and under the heating process with sodium, forming sodium cellulose 
causes a change in crystal type from I to II $[26,27]$. The formation of crystals is also affected by the heating, where hydrolysis is carried out to cut cellulose into shorter chains, whereas the shape of the crystal depends on the heating temperature, the higher the temperature, the more the shape of the crystal [28].

\section{CONCLUSION}

As the conclusion, the highest yield of 93\% of MCC was obtained from the hydrolysis of alpha-cellulose using cellulase from Macrotermes gilvus. The optimum Hydrolysis condition was achieved at $50^{\circ} \mathrm{C}$, pH 6.0, in $2 \mathrm{~h}$, which produced $80 \%$ yield of MCC. The Macrotermes gilvus was considered as the best source of cellulase with suitable activity for the preparation of MCC. Cellulase from termites Macrotermes gilvus has a high activity with clear zone area $49 \mathrm{~mm}$. Organoleptic and qualitative test, FTIR spectrum, PSA and XRD, there was a similar characteristic of crystalline between MCC from kapok alpha-cellulose and Avicel PH 101 as a reference.

\section{ACKNOWLEDGMENT}

We would like to thanks the Directorate of Research and Engagement, Universitas Indonesia and Ministry of Research, Technology and the Higher Education Republic of Indonesia for supporting research grant (PTM) to the authors.

\section{FUNDING}

Nil

\section{AUTHORS CONTRIBUTIONS}

All authors have equal contributions

\section{CONFLICT OF INTERESTS}

All authors declare there is no conflict of interest.

\section{REFERENCES}

1. Friday ET, James O, Gabriel A. In vitro growth and inhibition studies of ceiba pentandra leaf: a common vegetable in nigeria. Int J Plant Physiol Biochem 2011;3:1.

2. Astika JM, Chandrawati C, Hendrajaya I, Soemarno, Yogi O. The exploration of alpha-cellulose in kapok fruit as raw material for rocket propellant production. Agri Res Tech: Open Access J 2017;12:1-8.

3. Hindi SSZ. Microcrystalline cellulose: the inexhaustible treasure for the pharmaceutical industry. Nanosci Nanotech Res 2017;4:17.

4. Fuadi AM, Harismah K. Perbandingan efektifitas pembuatan glukosa dari kertas bekas secara hidrolisis asam dan enzim. Jurn Tek Bah Al 2017;1:6.

5. Suryadi H, Sutriyo, Sari HR, Rosikhoh D. Preparation of microcrystalline cellulose from water hyacinth powder by enzymatic hydrolysis using cellulase of local isolate. J Young Pharm 2017;9:19-23.

6. Fagbohunka BS, Okonji RE, Adenike AZ. Purification and characterization of cellulase from Termite Ametermes eveuncifer (Silverstri) soldiers. Int J Bio 2016;9:2-7.

7. Archibalt FS, Bourbonais R, Jurasek L, Paice MG, Reid ID. Kraft pulp bleaching and delignificatonby Trametes versicolor. J Biotech 1997;53:215-36.
8. Suryadi H, Lestari YPI, Mirajunnisa, Yanuar A. Potential of cellulase of Chaetomium Globosum for preparation and characterization of microcrystalline cellulose from water hyacinth (Eichhornia crassipes). Int J Appl Pharm 2019;11:140-6.

9. Begum MF, Absar N. Purification and characterization of intracellular cellulase from Aspergillus oryzae ITCC-4857.01. The Kor Soc of Myc 2009;37:121-7.

10. Hasanah N, Saskiawan I. Aktivitas selulase isolat jamur dari limbah media tanam jamur merang. Pros Sem Nas Masy Biodiv Indon 2015;1:1110-5.

11. United States Pharmacopoeial Convention. The United States Pharmacopeia, USP 30/The National Formulary, NF 25. Rockville, MD: U. S. Pharmacopeial Convention. Inc; 2007. p. 2635.

12. Harmita. Analisis Fisiko Kimia. Depok: Departemen Farmasi FMIPA Universitas Indonesia; 2006.

13. British Pharmacopoeia Commission. British Pharmacopoeia. London: Stationery Office; 2008.

14. Balat M, Balat H, Oz C. Progress in bioethanol processing. Prog Energy Combust Sci 2008;34:551-73.

15. Moreira MT, Viacava C, Vidal G. Fed-batch decolorization of poly R-478 by Trametes versicolor. Braz Arch Biol Technol 2004;47:179-83.

16. Knezevic A, Stajic M, Jovanovic VM, Kovacevic V, Cilerdzic J, Milovanovic I, et al. Induction of wheat straw delignification by Trametes species. Sci Rep 2016;6:1-12.

17. Bollag DM, Edelstein SJ, Protein methods willey-liss inc. New York; 1991.

18. Rousseau RW, Ferrell JK, Reardon RF. Synthesis of diethylaminoethyl cellulose on cotton fabric. Indust Eng Chem Prod Res Dev 1986;3:250-2.

19. Boyer RF. Modern experimental biochemistry. $2^{\text {nd }}$ Edition. California: The Benjamin Cummings Publishing Company; 1993.

20. Zhang YH, Himmel ME, Mielenz JR. Outlook for cellulase improvement: screening and selection strategies. Biotechnol Adv 2006;24:452-81.

21. Mandels $M$, Reese ET. Introduction of cellulose in fungi by cellobiose. J Bact 1976;79:816-26.

22. Whittaker JR. Principles of enzymology for the food sciences. 2nd Edition. New York: Marcel Decker; 1994. p. 67-70.

23. Meryandini A, Widosari W, Maranatha B, Sunarti TC, Rachmania N, Satria $H$. Isolasi bakteri selulolitik dan karakterisasi enzimnya. Makara J Sci 2009;13:33-8.

24. Deng T, Cui X, Qi Y, Wang Y, Hou X, Zhu Y. Conversion of carbohydrates into 5-hydroxymethylfurfural catalyzed by $\mathrm{ZnCl}_{2}$ in water. Chem Commun 2012;48:5494-6.

25. Das K, Ray D, Bandyopadhyay N, Ghosh T, Mohanty A, Misra M. A study of the mechanical: thermal and morphological properties of microcrystalline cellulose particles prepared from cotton slivers using different acid concentrations. Cellulose 2009;16:783-93.

26. Mandal A, Chakrabarty D. Isolation of nanocellulose from wax sugarcane bagasse (SCB) and its characerization. Carbohydrate Polymer 2011;86:1291-9.

27. Klemm D, Philipp B, Heinze U, Heinze T, Wegenknect W. Comprehensive cellulose chemistry. Willey FCH 1998;2:31-43.

28. Aulton ME. Aulton's pharmaceutics: the design and manufactures of medicines. $3^{\text {rd }}$ Edition. New York: Churchill Livingstone Elsevier; 2007. p. 412, 450. 